九州大学学術情報リポジトリ

Kyushu University Institutional Repository

\title{
Effect of Specific Ions in Agar on Antibiotic Production by Burkholderia glumae
}

\author{
Yamasaki, Shuichi \\ Laboratory of Plant Pathology, Faculty of Agriculture, Kyushu University \\ Furuya, Naruto \\ Laboratory of Plant Pathology, Faculty of Agriculture, Kyushu University \\ Matsuyama, Nobuak i \\ Laboratory of Plant Pathology, Faculty of Agriculture, Kyushu University
}

https://doi.org/10.5109/24218

出版情報：九州大学大学院農学研究院紀要. 42 (3/4)，pp.309-314，1998-03. Kyushu University バージョン：

権利関係 : 


\title{
Effect of Specific Ions in Agar on Antibiotic Production by Burkholderia glumae
}

\author{
Shuichi Yamasaki*, Naruto Furuya and Nobuaki Matsuyama \\ Laboratory of Plant Pathology, Faculty of Agriculture, \\ Kyushu University 46-01, Fukuoka 812-8581, Japan \\ (Received October 31, 1997 and accepted December 3, 1997 )
}

\begin{abstract}
Burkholderia glumae produced antibiotic substance(s) on agar plate media, but none in various liquid media. Some minor elements in agar were considered to be involved in the antibiotic production. $\mathrm{K}^{+}, \mathrm{Ca}^{2+}, \mathrm{Mg}^{2+}$ and $\mathrm{NH}_{4}^{+}$were shown to play significant roles in the production by culturing the bacterium in liquid media supplemented with various inorganic chemicals. Highest production was observed when $B$. glumae was cultured in the liquid medium containing a mixture of $\mathrm{MgCl}_{2}, \mathrm{KCl}$ and $\mathrm{CaCl}_{2}$. No antibiotic production was observed in $\mathrm{PGC}$ broth containing $\mathrm{MgSO}_{4}$ which was substituted for $\mathrm{MgCl}_{2}$ or $\mathrm{Mg}\left(\mathrm{NO}_{3}\right)_{2}$. These results suggest that specific cations and anions are involved in antibiotic(s) production by B. glumae.
\end{abstract}

\section{INTRODUCTION}

In previous papers (Wakimoto et al., 1986; Furuya et al., 1992a), it was shown that Burkholderia glumae has abilities to produce antibiotic substance(s) against various phytopathogenic bacteria including Ralstonia solanacearum and to suppress bacterial wilt of tomato under controlled conditions (Furuya et al., 1991; 1992b). Attempts to obtain a large amount of the antibiotic substance failed because it was not produced in liquid media. Consequently, elements in agar were considered to be important factors in production of the antibiotic substance(s) (Yamasaki et al., 1993; 1994). In this paper, qualitative and quantitative effects of some elements (cations and anions) on the antibiotic production were described.

\section{MATERIALS AND METHODS}

\section{Bacterial strains}

Bacterial strains used in this study were derived from the culture collection of the Laboratory of Plant Pathology, Faculty of Agriculture, Kyushu University. Seven strains of B. glumae were used as the producers of the antibiotics. $R$. solanacearum C319 was used as an indicator bacterium for the antibiotic substance(s).

\section{Detection of antibiotic production}

B. glumae was cultured on YPDA ( $10 \mathrm{~g}$ of yeast extract, $10 \mathrm{~g}$ of peptone, $20 \mathrm{~g}$ of Dglucose, $15 \mathrm{~g}$ of agar, 1 liter of water, $\mathrm{pH} 7.0$ ), PSA $\left(2 \mathrm{~g}\right.$ of $\mathrm{Na}_{2} \mathrm{HPO}_{4} \cdot 12 \mathrm{H}_{2} \mathrm{O}, 0.5 \mathrm{~g}$ of $\mathrm{Ca}\left(\mathrm{NO}_{3}\right)_{2} \cdot 4 \mathrm{H}_{2} \mathrm{O}, 5 \mathrm{~g}$ of sucrose, $15 \mathrm{~g}$ of agar, 1 liter of potato (300 g) decoction, $\mathrm{pH} 7.0$ )

\footnotetext{
* Present address: Oita Prefectural Agricultural Research Center, Oita 872-0103, Japan.
} 
and TTC (10g of peptone, $5 \mathrm{~g}$ of D-glucose, $1 \mathrm{~g}$ of casein, $18 \mathrm{~g}$ of agar, $50 \mathrm{ppm}$ of 2,3,5triphenyltetrazorium chloride, 1 liter of water) media at $30^{\circ} \mathrm{C}$ for $72 \mathrm{hr}$. After the bacteria were cultured on the media, the agar plates were frozen at $-20^{\circ} \mathrm{C}$ for longer than $2 \mathrm{hr}$ and thawed at room temperature for $2 \mathrm{hr}$. By these treatments, exudate was obtained from the culture plates. The exudate was sterilized by filtration through a Millipore filter $(0.2 \mu \mathrm{m})$ and antibiotic activity was estimated by the penicillin-cup method.

To investigate the production of antibiotic substance in liquid media, B. glumae was cultured in YPD, PS and TTC liquid media at $30^{\circ} \mathrm{C}$ for 6 days under still conditions. The cultured fluid was sterilized by filtration as described above and the presence of antibiotic was examined by the penicillin-cup method.

\section{Production of antibiotic substance(s) in the agar-extract amended (AePGC) broth}

AePGC broth (10 $\mathrm{g}$ of peptone, $5 \mathrm{~g}$ of D-glucose, $1 \mathrm{~g}$ of casein, 1 liter of agar-extract solution) was used to investigate the effect of agar-extract on the antibiotic production by B. glumae. Agar-extract solution was prepared by suspending a certain grams of agar powder (Katayama Chemical Co. Ltd.) in 1 liter of distilled water. Agar suspension was stirred overnight at $5{ }^{\circ} \mathrm{C}$, and filtered through a filter paper. Concentration of agar-extract solution was expressed as the amount (gram) of agar powder which was added to 1 liter of distilled water. B. glumae was cultured in AePGC broth at $30^{\circ} \mathrm{C}$ for 6 days under still conditions. Antibiotic production in the broth was examined by the penicillin-cup method.

\section{Effects of minor elements in agar on antibiotic production}

Since $30 \mathrm{~g}$ of agar powder was calculated to contain $\mathrm{NaCl}\left(3.2 \times 10^{\circ} \mathrm{mM}\right), \mathrm{KCl}(6.6 \times$ $\left.10^{-2} \mathrm{mM}\right), \mathrm{CaCl}_{2}\left(2.8 \times 10^{-1} \mathrm{mM}\right), \mathrm{MgCl}_{2}\left(4.4 \times 10^{-1}\right), \mathrm{NH}_{4} \mathrm{Cl}\left(6.2 \times 10^{-2} \mathrm{mM}\right)$ and $\mathrm{Na}_{3} \mathrm{PO}_{4}$ $\left(1.1 \times 10^{-1} \mathrm{mM}\right)$ according to Uzuka (1992), a liquid medium, PGC broth (10g of peptone, $5 \mathrm{~g}$ of D-glucose, $1 \mathrm{~g}$ of casein, 1 liter of distilled water), was amended with each or mixtures of the inorganic chemicals so that the medium contained the same concentration of the respective elements. B. glumae was cultured in the amended PGC broth at $30^{\circ} \mathrm{C}$ for 6 days under still conditions. The effect of elements on the antibiotic production was estimated by the penicillin-cup method.

\section{RESULTS}

\section{Antibiotic production by $B$. glumae in various liquid media}

The exudate from the culture plates showed anti- $R$. solanacearum activity, but the culture filtrates of YPD, PS and TTC liquid media did not show any anti- $R$. solanacearum activity (Table 1). As shown in Table 2, the antibiotic production was observed in AePGC liquid medium which contained the agar-extract from $5 \mathrm{~g}$ agar powder.

\section{Effect of various elements in agar on antibiotic production by $B$. glumae}

As can be seen in Table 3, the antibiotic production was observed in PGC broth supplemented with $\mathrm{KCl}, \mathrm{CaCl}_{2}, \mathrm{MgCl}_{2}$ or $\mathrm{NH}_{4} \mathrm{Cl}$. Highest antibiotic production was recorded in $\mathrm{PGC}$ broth containing $\mathrm{MgCl}_{2}$. However, the degree of production was lower than that in AePGC medium. A test was performed to examine cumulative effect of two or more kinds of elements on the production. The cumulative effect of cation on the 
Table 1. Production of antibiotic substance(s) by Burkholderia glumae

\begin{tabular}{|c|c|c|c|}
\hline \multirow[b]{2}{*}{$\begin{array}{l}\text { B. glumae } \\
\text { strain }\end{array}$} & \multicolumn{3}{|c|}{ Anti-Ralstonia solanacearum activity } \\
\hline & $\begin{array}{l}\text { shown by plate- } \\
\text { chloroform method" }\end{array}$ & $\begin{array}{l}\text { of the exudate }{ }^{r} \text { from } \\
\text { agar medium }\end{array}$ & $\begin{array}{l}\text { of the culture } \\
\text { filtrate }\end{array}$ \\
\hline N7401 & - & - & - \\
\hline N7503 & + & \pm & - \\
\hline 805 & +++ & + & - \\
\hline $\mathrm{N} 750$ & +++ & + & - \\
\hline $\mathrm{Ku} 8113$ & + & \pm & - \\
\hline Ku8117 & - & - & - \\
\hline Ku8121 & +++ & + & - \\
\hline
\end{tabular}

a) Activity index (semidiameter of inhibition zone): - , not detected; \pm , faint activity; + , less than $5 \mathrm{~mm}$; +++, greater than $10 \mathrm{~mm}$.

b) B. glumae was spot-inoculated on YPDA, PSA and TTC plates and cultured at $30^{\circ} \mathrm{C}$ for 3 days. Aftert treatment with chloroform vapor, an indicator bacterium, $R$. solanacearum, was overlaid.

c) YPDA, PSA and TTC media on which B. glumae was cultured at $30^{\circ} \mathrm{C}$ for 3 days were frozen at $-20^{\circ} \mathrm{C}$ for above $2 \mathrm{hr}$ and thawed at room temperature to obtain the exudate.

d) YPD, PS and TTC liquid media in which B. glumae was cultured at $30^{\circ} \mathrm{C}$ for 6 days were filtered through Millipore filter $(0.2 \mu \mathrm{m})$.

Table 2. Effect of agar-extract on the antibiotic production by Burkholderia glumae

\begin{tabular}{|c|c|c|c|c|c|c|}
\hline \multirow{3}{*}{$\begin{array}{l}\text { B. glumae } \\
\text { strain }\end{array}$} & \multicolumn{6}{|c|}{ Width of inhibition zone ${ }^{a)}$} \\
\hline & \multicolumn{4}{|c|}{ Concentration of agar-extract ${ }^{\text {h) }}$} & \multicolumn{2}{|c|}{ ( $\mathrm{g}$ of agar/l of water) } \\
\hline & 0.0 & 1 & 5 & 15 & 30 & 50 \\
\hline N7401 & - & NT & NT & NT & NT & - \\
\hline N7503 & - & NT & NT & NT & NT & + \\
\hline 805 & - & - & +++ & +++ & NT & $\mathrm{NT}$ \\
\hline N750 & - & - & +++ & +++ & +++ & +++ \\
\hline Ku8113 & - & NT & $\mathrm{NT}$ & NT & NT & + \\
\hline Ku8117 & - & NT & NT & NT & NT & - \\
\hline Ku8121 & - & - & +++ & +++ & NT & NT \\
\hline
\end{tabular}

a) Activity index (semidameter of inhibition zone): -, not detected; + , less than $5 \mathrm{~mm}$; +++, greater than $10 \mathrm{~mm}$; NT, not tested. Ralstonia solanacearum C319 was used as an indicator.

b) Concentration of agar-extract was expressed as the amount (gram) of agar powder which was added in 1 liter of distilled water. 
production was remarkable when the mixture of $\mathrm{MgCl}_{2}, \mathrm{KCl}$ and $\mathrm{CaCl}_{2}$ was added to PGC broth (Table 4). As shown in Table 5, the production was observed in PGC broth containing $\mathrm{MgCl}_{2}$ or $\mathrm{Mg}\left(\mathrm{NO}_{3}\right)_{3}$, but not $\mathrm{MgSO}_{4}$.

Table 3. Effect of various cations on the antibiotic production by Burkholderia glumae N750

\begin{tabular}{|c|c|c|c|c|}
\hline \multicolumn{3}{|c|}{ Cation } & \multirow[b]{2}{*}{ Activity } & \multirow[b]{2}{*}{$\mathrm{pH}$} \\
\hline $\mathrm{R}^{+ \text {b) }}$ & $\mathrm{R}^{3+c)}$ & $R^{3+d)}$ & & \\
\hline $\mathrm{Na}$ & & & $0.0 \mathrm{~h}^{\mathrm{f}}$ & $7.22 \mathrm{~m}$ \\
\hline $\mathrm{K}$ & & & $1.3 j$ & $6.69 \mathrm{k}$ \\
\hline \multirow{4}{*}{$\mathrm{NH}_{4}$} & & & $0.9 \mathrm{hj}$ & $6.87 \mathrm{j}$ \\
\hline & $\mathrm{Mg}$ & & $3.7 \mathrm{k}$ & $6.27 \mathrm{~m}$ \\
\hline & $\mathrm{Ca}$ & & $0.3 \mathrm{~h}$ & $6.81 \mathrm{j}$ \\
\hline & & $\mathrm{P}$ & $0.0 \mathrm{~h}$ & $7.29 \mathrm{~h}$ \\
\hline \multirow[t]{2}{*}{$\mathrm{Na}, \mathrm{K}, \mathrm{NH}_{4}$} & $\mathrm{Mg}, \mathrm{Ca}$ & $\mathrm{P}$ & $5.4 \mathrm{~m}$ & $6.33 \mathrm{~m}$ \\
\hline & Cont. (AePGC) & & $5.6 \mathrm{~m}$ & $6.24 \mathrm{~m}$ \\
\hline
\end{tabular}

a) Cultured at $30^{\circ} \mathrm{C}$ for 6 days. b) Monovalent cation. c) Divalent cation.

d) Trivalent cation.

e) Semidiameter of inhibition zone (mm). Ralstonia solanacearum $\mathrm{C} 319$ was used as an indicator. f) Values within each column followed by the same letter are not significantly different $(P=0.05)$ according to Duncan's multiple range test.

Table 4. Cumulative effects of various cations on the antibiotic production by Burkholderia glumae N750

\begin{tabular}{|c|c|c|c|c|}
\hline \multicolumn{3}{|c|}{ Cation } & \multirow[b]{2}{*}{ Activity } & \multirow[b]{2}{*}{$\mathrm{pH}$} \\
\hline $\mathrm{R}^{+(\mathrm{u})}$ & $\mathrm{R}^{20}$ & $\mathrm{R}^{3+(s)}$ & & \\
\hline $\mathrm{K}, \mathrm{NH}_{4}$ & $\mathrm{Mg}, \mathrm{Ca}$ & & $6.5 h^{n}$ & $6.08 \mathrm{~h}$ \\
\hline $\mathrm{K}, \mathrm{NH}_{4}$ & $\mathrm{Mg}$ & & $5.4 \mathrm{hj}$ & $6.25 \mathrm{jk}$ \\
\hline $\mathrm{K}$ & $\mathrm{Mg}, \mathrm{Ca}$ & & $7.0 \mathrm{~h}$ & $6.10 \mathrm{~h}$ \\
\hline & $\mathrm{Mg}, \mathrm{Ca}$ & & $4.4 \mathrm{j}$ & $6.21 \mathrm{j}$ \\
\hline$K$ & $\mathrm{Mg}$ & & $5.5 \mathrm{hj}$ & $6.27 \mathrm{jk}$ \\
\hline $\mathrm{NH}_{4}$ & $\mathrm{Mg}$ & & $1.6 \mathrm{k}$ & $6.31 \mathrm{k}$ \\
\hline $\mathrm{K}, \mathrm{NH}_{4}$ & & & $0.0 \mathrm{~m}$ & $6.65 \mathrm{~m}$ \\
\hline $\mathrm{K}$ & $\mathrm{Ca}$ & & $0.0 \mathrm{~m}$ & $6.62 \mathrm{~m}$ \\
\hline $\mathrm{Na}, \mathrm{K}, \mathrm{NH}_{4}$ & $\begin{array}{c}\mathrm{Mg}, \mathrm{Ca} \\
\text { Cont. (AePGC) }\end{array}$ & $\mathrm{P}$ & $\begin{array}{l}5.4 \mathrm{j} \\
5.6 \mathrm{j}\end{array}$ & $\begin{array}{l}6.33 \mathrm{k} \\
6.24 \mathrm{jk}\end{array}$ \\
\hline
\end{tabular}

a) Cultured at $30^{\circ} \mathrm{C}$ for 6 days. b) Monovalent cation. c) Divalent cation. d) Trivalent cation. e) Semidiameter of inhibition zone (mm). Ralstonia solanacearum C319 was used as an indicator. f) Values within each column followed by the same letter are not significantly different ( $(P=0.05)$ according to Duncan's multiple range test. 
Table 5. Effcet of various anions on the antibiotic production by Burkholderia glumae N750

\begin{tabular}{cccc}
\hline & Anion & & \\
\hline $\mathrm{R}^{-\mathrm{h})}$ & $\mathrm{R}^{2-c}$ & Activity & $\mathrm{pH}$ \\
\hline $\mathrm{MgCl}_{2}$ & & $3.7 \mathrm{~h}^{\mathrm{(})}$ & $6.27 \mathrm{~h}$ \\
$\mathrm{Mg}$ & & $3.9 \mathrm{~h}$ & $6.21 \mathrm{~h}$ \\
& $\left.\mathrm{MgSO}_{4}\right)_{2}$ & $0.0 \mathrm{j}$ & $6.35 \mathrm{~h}$ \\
\hline
\end{tabular}

a) Cultured at $30^{\circ} \mathrm{C}$ for 6 days. b) Monovalent anion. c) Divalent anion. d) Semidiameter of inhibition zone (mm). Ralstonia solanacearum C319 was used as an indicator. e) Values within each column followed by the same letter are not significantly different $(P=0.05)$ according to Duncan's multiple range test.

\section{DISCUSSION}

Antibiotic production by $B$. glumae was observed in solid agar media, but not in liquid media. This phenomenon indicated an important role of element(s) in agar for the production (Furuya et al, 1992a). Since the existence of six ions $\left(\mathrm{Na}^{+}, \mathrm{K}^{+}, \mathrm{NH}_{4}{ }^{+}, \mathrm{Ca}^{2+}\right.$, $\mathrm{Mg}^{2+}$ and $\mathrm{P}^{3+}$ ) in agar was formerly documented (Uzuka, 1992), the effect of these minor elements on the production was examined. Among these cations tested, $\mathrm{K}^{+}, \mathrm{NH}_{4}^{+}, \mathrm{Mg}^{2+}$ and $\mathrm{Ca}^{2+}$ were revealed to participate in the antibiotic production. The effect of $\mathrm{Mg}^{2+}$ was particularly prominent. Moreover, highest production was recorded when the bacterium was cultured in PGC liquid medium containing the mixture of $\mathrm{MgCl}_{2}, \mathrm{KCl}$ and $\mathrm{CaCl}_{2}$. Thus, in liquid culture conditions, the presence of specific cations was necessary for the production of the antibacterial substance(s). The antibiotic production was observed in $\mathrm{PGC}$ broth containing $\mathrm{MgCl}_{2}$ or $\mathrm{Mg}\left(\mathrm{NO}_{3}\right)_{2}$, but not in the broth supplemented with $\mathrm{MgSO}_{4}$, suggesting that anions also play an important role(s) for the production.

Like the case of $B$. glumae, $\mathrm{Mg}^{2+}$ was shown to affect magnesidin production by $P$. magnesiorubra nov. sp. ATCC21856 (Gandhi et al., 1973) and Vibrio gazogenes ATCC29988 (Imamura et al., 1994). The effect of minor element, ion, has also been reported in pyoveridine production by $P$. fluorescens (Loper and Lindow, 1994).

The mechanisms of the promotive effects on antibiotic production by amendment of the minor nutrients in agar have not been elucidated in the present study. This will be an important subject for future study.

\section{REFERENCES}

Furuya, N., Y. Kushima, K. Tsuchiya, N. Matsuyama and S. Wakimoto 1991 Protection of tomato seedlings by pre-treatment with Pseudomonas glumae from infection with Pseudomonas solanaceamim and its mechanisms. Ann. Phytopathol. Soc. Jpn., 57: 363-370

Furuya, N., Y. Kushima and N. Matsuyama 1992a Production of antibacterial substances by Pseudomonas glumae. J. Fac. Agr., Kyushu Univ., 37: 149-158

Furuya, N. and N. Matsuyama $1992 \mathrm{~b}$ Biological control of the bacterial wilt of tomato with antibioticproducing strains of Pseudomonas glumae. J. Fac. Agr., Kyushu Univ., 37: 159-171

Gandhi, M., J. Nazareth, P. Divekar, H. Kohl and N. De Souza 1973 Magnesidin, a novel magnesiumcontaining antibiotic. J. Antibiotics, 26: 797-798 
Imamura, N., K. Asachi and H. Sano 1994 Magnesidin A, a component of marine antibiotic magnesidin, produced by Vibrio gazogenes ATCC 29988. J. Antibiotics, 47: 257-261

Loper, J.E. and S.E. Lindow 1994 A biological sensor for iron available to bacteria in their habitats on plant surfaces. Appl. Environ. Microbiol., 60: 1934-1941

Uzuka, Y. 1992 Yeasts as oligotrophic microorganisms- a new concept derived from soil yeast physiology. Kagaku To Seibutsu, 30: 431-440

Wakimoto, S., K. Hirayae, K. Tsuchiya, Y. Kushima, N. Furuya and N. Matsuyama 1986 Production of antibiotics by plant pathogenic pseudomonads. Ann. Phytopathol. Soc. Jpn., 52: 835-842

Yamasaki, S., N. Furuya, Y. Kushima, Y. Takanami and N. Matsuyama 1993 The antibiotics produced by Pseudomonas glumae (1). Conditions for antibiotic production (Abstr.). Ann. Phytopathol. Soc. Jpn., 59: 721-722

Yamasaki, S., N. Furuya, Y. Kushima, Y. Takanami and N. Matsuyama 1994 The antibiotics produced by Pseudomonas glumae (2). Conditions for antibiotic production (2) (Abstr.). Ann. Phytopathol. Soc. Jpn., 60: $370-371$ 